\title{
Implementation Of E-Government In Improving Public Service:The Policy of the Directorate General of Taxes at the South Malang, in Indonesia
}

\author{
Dinda Intan Permata Sari, Roos Widjajani, and Tauchid Noor \\ University of Merdeka Malang \\ Indonesia
}

\begin{abstract}
Taxes are a significant source of state revenue for implementing and improving national development to achieve prosperity and public welfare. Taxes come from the community and are reused for the benefit of the community. People who are active taxpayers are called taxpayers. The purpose of this study is to analyze the implementation of E-Government implementation to improve Public Service based on the Policy of the Director-General of Taxes Number KEP-136/PJ/2014 concerning Electronic Tax Invoice Services at the Pratama Tax Office, South Malang, and what supports and hinders the implementation of e-commerce. Government to improve Public Service based on the Director-General of Taxes Policy. The research was conducted at the South Malang Primary Tax Office, and the research informants were employees of the Tax Office who were directly related to the E-Tax Invoice service. The results of this study indicate that the service requirements after the implementation of e-government programs, especially in the service of managing Electronic Tax Invoices at the Malang Tax Service Office, are not by the objectives of implementing e-government where the government wants to provide services that are more concise, easy and simple. The completion time of the E-Tax Invoice service at the South Malang Tax Service Office after the e-government program is implemented only takes one day. Assisted by sophisticated equipment and technology, the Malang City Tax Service Office employees can carry out administrative management, especially in the E-Tax Invoice service, in a short, easy, and fast time. The implementation of e-government, especially in tax e-invoice services, at the level of taxpayer satisfaction with the services provided by the Tax Service Office is still lacking due to the lack of understanding of taxpayers regarding the electronic invoice filling process.
\end{abstract}

Key words : E-Government, Public Service, Taxes.

\section{INTRODUCTION}

Taxes are a significant source of state revenue for implementing and improving national development to achieve prosperity and public welfare. Taxes come from the community and are reused for the benefit of the community. People who are active taxpayers are called taxpayers. According to their administrative needs, the one who serves these taxpayers is the Tax Service Office. By the Director-General of Taxes Regulation Number PER-28/PJ/2012 concerning Places for Business Reporting and Tax Services for Taxpayers in the Scope of the Tax Service Office that to provide legal certainty, improve services, orderly administration and supervision, as well as implement rights and fulfill tax obligations for Taxpayers and or confident Taxable Entrepreneurs whose services are carried out at the Tax Service Office within the Regional Office of the Directorate General of Taxes, Jakarta Special, and the Middle Tax Service Office.

Efforts to improve tax services to be more optimal, the government, through the Directorate General of Taxes, develops services by utilizing e-government technology applied in Tax Service Offices throughout Indonesia so that tax service frauds can be minimized improved service improvements can be achieved. Through the development of e-government, tax management systems and work processes are arranged in the tax service office environment by optimizing the use of the existing information technology queue at the Tax Office.

ElectronicInvoicing is a form of service provided by the Directorate General of Taxes which is intended to provide convenience, security, and convenience for the Taxable Entrepreneur in carrying out tax obligations, especially in the case of making tax invoices which are also an integral part of the preparation of the Value Added Tax Return. Meanwhile, the benefits for the Directorate General of Taxes are as a means to minimize the occurrence of fictitious tax invoices and misuse by irresponsible 
parties that can have an impact on the state, so that e-invoices can function as supervision of the use of tax invoices in the event of compliance with taxpayers.

However, even though e-government has been implemented at the South Malang Tax Service Office, the service of the E-Tax Invoice administration process is mainly hampered due to the ignorance of the Taxpayer in filling out the electronic Tax Invoice in the E-Faktur application. Then the absence of a forum such as an online forum causes low participation of taxpayers in implementing e-government at the Tax Service Office. They cannot express their aspirations, opinions, and criticisms of services at the Tax Service Office, even though criticism and suggestions from taxpayers are significant to improve the quality of services provided by the Tax Service Office in the future, the implementation of e-government has been implemented in Malang as shown in Figure 1.

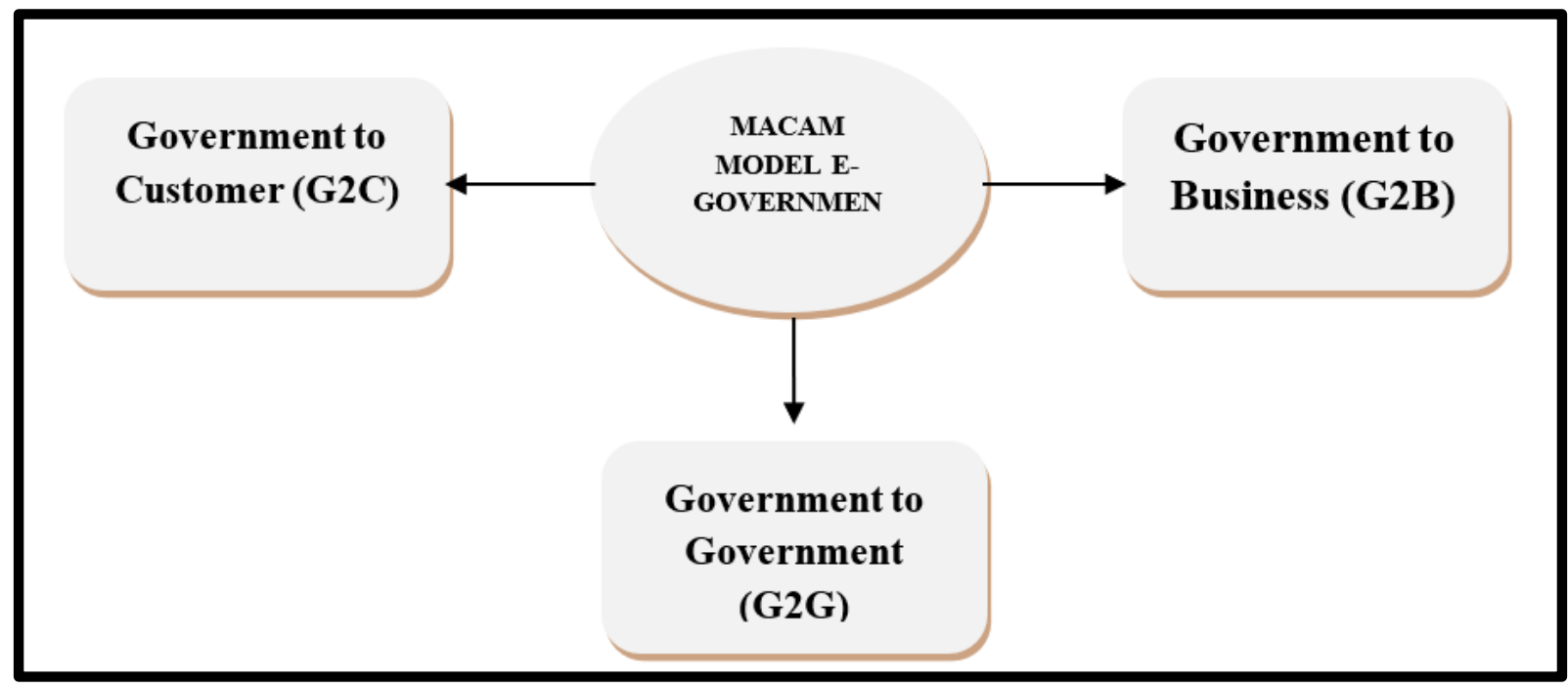

Figure 1. Various Models or Forms of E-Government

However, after E-Government is implemented, the E-Tax service fee is now free, and the Electronic Invoice service completion time is only one day, which is considered very efficient for Taxpayers because it saves time and service costs. Electronic In voice Users can also take care of all their administrative matters without queue long at the Tax Office to be served. All tax information can be accessed through the online tax website. Administrative processes such as E-Tax Invoices can also be carried out by taxpayers at home online. They can fill in data, manage taxes online, and print proof of tax payments wherever they are, and direct tax payments can be paid at any Post Office.

The formulation of the research problem is: How is the Implementation of E-Government Implementation to improve Public Service based on the Policy of the Director-General of Taxes Number KEP-136/PJ/2014 concerning Electronic Tax Invoice Services at the South Malang Pratama Tax Office, and what supports and hinders the implementation of E-Government implementation in an effort Public Service improvement based on the Director-General of Taxes' Policy Number KEP136/PJ/2014 concerning Electronic Tax Invoice Services at the South Malang Primary Tax Office.

\section{THEORETICAL REVIEW}

Policies are formulated and then made in a positive form, such as law, and then implemented or implemented, but a policy must be implemented or implemented to have the desired impact or goal. Policy implementation is the hardest thing because problems that are sometimes not found in the concept arise in the field. In addition, the main threat is the consistency of implementation. Policy implementation can be a dynamic process, where policy implementers carry out an activity or activity so that they will get a result that is by the goals or objectives of the policy itself. The success of policy implementation can be measured or seen from the process and the achievement of the final results, namely: whether or not the goals will be achieved. According to ${ }^{[1]}$, Policy Implementation is: "Actual policy implementation is not only concerned with the mechanism of elaboration of political decisions into routine procedures through bureaucratic channels, but more than that, it involves issues of conflict, decisions and who is responsible. what do you get from a policy?" 


\section{RESEARCH METHODS}

In this study, a qualitative research approach was used. To quote Kirk and Miller's explanation in Lexy J. Moleong's book Qualitative Research Methodology on the definition of qualitative research: "Qualitative research is a particular tradition in social science that is fundamentally dependent on observing humans in their area and relating to these people in their language. and in its terms". ${ }^{[2]}$ Qualitative research is carried out as an activity or process to obtain information from natural and normative conditions in the continuity of an activity object, which is then juxtaposed with solving a problem from a theoretical and empirical point of view.

Research sites, Researchers researched at the South Malang Primary Tax Office located at Jl. Merdeka Utara No.3, Kiduldalem, Klojen, Malang City, East Java 65119, Indonesia.Telephone:(0341) 361121. Based on the objectives and focus of this study, the researcher chose the location because it was by the discipline of Public Administration, as well as being a lesson and knowledge of the extent to which E-Government was implemented to improve public service in the E-Tax Invoice service at the Pratama Tax Office in Malang City. It is a service forum for people who have taxable businesses or Taxable Entrepreneurs to fulfill their administrative needs.

Research Informants, are used to provide information about the situation and condition of the research background. The informants in this study were Tax Office employees who were directly related to the E-Tax Invoice service. In this study, the data were analyzed using several steps by the theory of ${ }^{[3]}$, namely analyzing data with three stages, namely data condensation, presenting data, and drawing conclusions or verification. Data condensation refers to the process of selecting, narrowing, simplifying, summarizing, and transforming data. This qualitative research is used to get an overview and understand the broad and deep situation and apparent problems regarding the Implementation of the Director-General of Taxes Policy Number KEP136/PJ/2014 concerning Tax Invoice Services.ShapedElectronics at the South Malang Primary Tax Office. Qualitative research utilizes open interviews to examine and understand an individual or group of people's attitudes, views, feelings, and behavior on the issue or thing being studied ${ }^{[4]}$. Qualitative research researches a natural setting or in the context of a whole that cannot be understood if separated from its context with the assumption that the act of observing influences what is seen, therefore the research relationship must take place in the whole in context for understanding so that it brings researchers to enter and involve some of their time in the location where the research is carried out.

\section{RESEARCH RESULT}

\subsection{Electronic Invoice Service Terms}

Based on the research results, service requirements, especially in the application of $e$-government, are many E-Faktur services at the South Malang Tax Service Office and cannot be said to be simple even though E-Faktur is a technology-based program. There are several different documents to manage the administrative process so that taxpayers can issue E-Tax Invoices. The requirements that are quite a lot are felt to be not by the objectives of implementing e-government where the government wants to provide more concise, easy, and simple services. The service requirements are deemed not to make the application of egovernment, especially in the E-Invoice service at the South Malang Tax Service Office, which makes it easier for taxpayers because of the many documents that must be met to have permission to issue an Electronic Invoice.

\subsection{Procedure or Stages of E-Invoice Service}

Based on the research results, the application of e-government electronic tax invoice services, the procedures and stages of service are a bit complicated because taxpayers and tax officers must take lots of steps. Therefore, in-depth socialization is needed for Taxpayers or Taxable Entrepreneurs so that they are not wrong in carrying out these procedures or stages. The tax employee must explain in detail and detail about the system, starting from submitting a Taxable Entrepreneur to issue a tax invoice to the understanding of Taxpayers regarding filling out electronic invoices independently.

\subsection{Performance and Readiness of Human Resources for South Malang Tax Service Office}

Based on research results regarding the application of e-government in the service of e-tax invoices on the performance and readiness of employees' human resources in providing services, it is deemed sufficient to meet the standards. However, some Human Resources employees are not very familiar with e-government programs. So, according to the head of the service section, training and socialization of these electronic-based programs will continue to be carried out to employees to achieve better readiness of human resources for employees to serve in the future. As well supervision from the office leadership will be further enhanced to prevent slumping the performance of the Tax Service Office employees to improve the quality of service. 


\subsection{Taxpayer Satisfaction or Taxable Entrepreneurs}

Service satisfaction in application-government especially in tax e-invoice services can be in the form of fast service, understanding of taxpayers about the process of filling out electronic invoices online quickly, and servers from the Tax Service Office which do not often have errors so that they do not hinder the administrative process of taxpayers. Likewise, based on the results of research on the application of e-government, especially in the service of e-tax invoices, the level of satisfaction of taxpayers with the services provided by the Tax Service Office is still lacking because of these things. Taxpayers complain because when the service takes place, the understanding and information by the employees of the Tax Service Office to the Taxable Entrepreneurs are still very lacking; the employees of the Tax Service Office tend to be in a hurry in providing services. Even though many Tax Service Offices do not fully understand the E-Invoice application. So the Taxable Entrepreneurs hope that the services provided by employees will be further improved.

\subsection{Taxpayer Participation}

The participation or participation of service users is indeed a must considered because it is essential in service progress. Active participation of service users will improve the service quality of an organization or service provider because they can find out what service users want and don't want. However, based on the results of research on the implementation of e-government in e-tax invoice services in terms of participation, it can be seen that taxpayer participation is still not very active due to the unavailability of online forums as a means or place where taxpayers or taxable entrepreneurs should be able to express their opinions, which can be in the form of complaints during the administrative process or complaints about the services they have received so far. Can help service providers, namely the South Malang Tax Service Office, improve the quality of their services. The participation of Taxpayers or Taxable Entrepreneurs is very much needed for the smoothness and convenience of their administrative processes.

\subsection{Infrastructure Supporting the Implementation of e-Gov at Tax Service Office South Malang.}

Penthe implementation of e-government in services at the South Malang Tax Service Office in terms of supporting infrastructure, based on the study results, it appears that the provision of infrastructure for employees is excellent using computers and sophisticated machines. The facilities in the form of sophisticated computers can support them in providing excellent service to all taxpayers. According to the employee, this facility dramatically speeds up their delivery of services and checks data from Taxpayers or Taxable Entrepreneurs who are confirmed at the South Malang Tax Service Office.

\section{CONCLUSIONS}

Based on the discussion that has been carried out in the previous chapter, the following conclusions are drawn: After implementing e-government programs, especially in the service of managing Electronic Tax Invoices at the South Malang Tax Service Office, are still quite a lot and cannot be said to be simple. The many requirements are deemed not to be by the objectives of implementing e-government where the government wants to provide more concise, easy, and simple services.

The completion time of the E-Tax Invoice service at the South Malang Tax Service Office after the e-government program is implemented only takes one day. Assisted by sophisticated equipment and technology, the Malang City Tax Service Office employees can carry out administrative management, especially in the E-Tax Invoice service, in a short, easy, and fast time.

The application of e-government in tax e-invoice services regarding the procedures and stages of service in South Malang can still be said to be a little complicated because there are so many steps that taxpayers and tax officers must take to complete an administrative process.

The application of e-government in electronic tax invoice services on the performance and readiness of employees' human resources in providing services is deemed sufficient to meet the standards. However, some Human Resources employees are not very familiar with electronic-based programs (e-government). So, according to the head of the service section, training and socialization of these electronic-based programs will continue to be carried out to employees to achieve better readiness of human resources for employees to serve in the future.

The application of e-government, especially in tax e-invoice services, at the level of satisfaction of taxpayers with services provided by the Tax Service Office is still lacking due to the lack of understanding of taxpayers regarding the process of filling out electronic invoices due to explanations or information obtained from tax officials at the time of service. Lasts very little.

Some suggestions to be conveyed by the author on this occasion include: The South Malang Tax Service Office needs to provide facilities in the form of a complaint number immediately responded to by the Tax Service Office. Taxpayers need a complaint number when they have difficulty using tax products, especially electronic invoices when they cannot come directly to the Tax Office. This is very much needed for the smooth completion of the Taxpayer's administrative process online. 
The South Malang Tax Service Office needs to increase socialization regarding service procedures so that Taxpayers or Taxable Entrepreneurs understand the existing systems as well as socialization related to the Online Tax website that can help taxpayers who lack information to access information that they do not or do not know through their smartphones or computers.

The South Malang Tax Service Office needs to conduct training for Tax Office employees who operate technology to be more professional in terms of efficiency and effectiveness of its services to Taxpayers or Taxable Entrepreneurs. The South Malang Tax Service Office needs to provide space for Taxpayers or Taxable Entrepreneurs to participate in public services, for example, installing a suggestion box at the Tax Service Office to find out what complaints, criticisms, and suggestions cannot be submitted directly by Taxpayers to employees. This will positively impact the advancement of services in the future.

The South Malang Tax Service Office needs to conduct in-depth socialization of the E-Faktur application to all Taxable Entrepreneurs. The joint socialization can be carried out in a room or hall that can accommodate Taxable Entrepreneurs; continuous socialization will positively impact understanding the E-Invoice application. This will benefit the Tax Office employees because they no longer need to explain in detail one by one to the Taxable Entrepreneurs. After all, socialization has covered all aspects of the information that the Taxable Entrepreneurs need to know and understand regarding E-Invoices.

\section{REFERENCES}

1. Chandler and Plano, 1988. Public Administration Reform. Jakarta-Bina Mulia.

2. Chief J. O. Udoji, 1981. Public Administration. Jakarta : PT. Archipelago Book.

3. Daniel A. Mazmanian and Paul A. Sabatier in Wahab, 2005. Implementation Stages. Jakarta.

4. Nafi, M. and Supriadi B., (2017), 'Strategies of Tourism. Development through cotourism Spectrum for Increasing Tourists' Visit', in Rural Research and Palanning Group and Palanning Group, pp. 75-85 